\title{
PARENTS' OPINION REGARDING THE USE OF DISTANCE LEARNING DURING COVID-19 PANDEMIC
}

\author{
DIANA-CRINA MARIN ${ }^{*}$, MUȘATA BOCOȘ ${ }^{2}$, \\ CECILIA-VERONICA CĂLIN ${ }^{3}$, ILDIKO CORDOȘ ${ }^{3}$
}

\begin{abstract}
Through this research paper, we aimed at studying the conditions in which distance learning processes have taken place at primary school level, during the temporal suspension of the face-to-face courses in pre-university education from Romania. We have also proposed some recommendations for decision-makers, educational researchers, and primary school practitioners. The questionnaire was applied in the online environment, between March 29th - May $5^{\text {th }}$ of 2020 . The sample of participants consisted of 1456 parents of primary school students. The results of the study revealed that some of the students faced various technical difficulties or emotional problems, and for some pupils, the level of motivation for learning decreased. Also, from the perspective of the parents, coherent and effective health education programs need to be implemented in schools, now or immediately after the end of this pandemic.
\end{abstract}

Keywords: learning at the distance, COVID-19 pandemic, school-family partnership, family involvement

1 Babes-Bolyai University, Doctoral School "Education, Reflection, Development", ClujNapoca, Romania

${ }^{2}$ Babes-Bolyai University, Faculty of Psychology and Educational Sciences, Cluj-Napoca, Romania

3 "Pavel Dan" Theoretical High School, Câmpia Turzii, Romania

*Corresponding author: crinadiana88@yahoo.com 


\section{Introduction. The Relationship Between the Quality of the School-Family Partnership and Academic Achievement During Covid-19 Pandemic}

The suspension of pre-university education courses, due to the current epidemiological context, has had negative effects on students' quality of life, as well as on the learning processes which take place exclusively in the online environment (Prime, Wade \& Browne, 2020). Researchers, practitioners, and decision-makers in the field of education are concerned with identifying optimal solutions that ensure the continuity of learning and the effectiveness of cooperation between school and family. Distance learning activities involve a higher involvement of the parent in the learning processes. The school-family partnership ensures the efficiency of the training activities carried out during this period, because the parents supervise the learning activity and offer the students immediate communicative feedback, fulfilling some of the teacher's attributions. High family involvement in children's education is correlated with good school results and more developed social skills (Powell, Son, File \& San Juan, 2010; Sheldon, 2003). Trust, mutual support, and respect ensure the functionality and resistance in time of the school-family partnership (Adams \& Christenson, 2000; Lazar \& Slostad, 1999). Adams \& Christenson (2010) showed that, at the level of primary education, the degree of parental trust in teachers is generally high. Addi-Raccach \& Arviv-Elyashiv (2008) highlighted that a high involvement of parents in education can negatively affect teachers' activity, who, in many situations, feel vulnerable and make efforts to avoid conflicts with parents. Bidirectional communication and decision-making transparency are some of the proposed solutions for strengthening the school-family relationship (Addi-Raccach \& Arviv-Elyashiv, 2008; Swick, 2003). Effective communication between parents and teachers has beneficial effects on children's school performance (Cox, 2005). The higher the socio-economic level of the family is, the more significant will be their involvement in the students' learning activity (Cakiroglu, A., \& Kuruyer, 2012). Also, studies on the factors that can influence the degree of family involvement in children's education have shown that the educational level of parents is an important predictor of family involvement (Cankar, Deutsch \& Kolar, 2009). Thus, in the current context, it is expected that parents with a high socioeconomic level to be more frequently involved in children's education, providing them with high-quality learning experiences (Hill \& Taylor, 2004; Izzo, Weissberg, Kasprow \& Fendrich, 1999, Pavalache-Ilie \& Tîrrdia, 2015). Also, it is considered that the more parents are actively involved 
in their children's education, the more time students will devote to learning activities (Schober \& Spiel, 2008). The pandemic has brought substantial changes in the parent-student-teacher relationship process, the effects of which need to be investigated through future studies. Previous studies have shown that many obstacles may arise that prevent parents from participating in school activities (multiple parental responsibilities, long distance between students' home and school, lack of time resources, etc.). In the context in which parents have become familiar with the use of online media, the effectiveness of parenting activities carried out in part or exclusively with the help of learning resources, could be tested to establish the efficacy of these activities on the quality of the school-family partnership. Also, the need arose for schools to be thoroughly prepared to deal with situations similar to the given one, by establishing coherent strategies and implementing health education programs (Trung, Hoang, Nguyen, \& Dinh, 2020; Horesh \& Brown, 2020).

\section{Learning at the Distance at the Primary School Level (Theoretical Foundation)}

Social distancing measures have influenced human behaviors and the way daily activities are carried out. Currently, teaching and learning takes place in the virtual environment, and educational systems from various countries around the world face extensive changes and challenges related to the organization of educational processes (Favale, Soro, Trevisan, Drago, \& Mellia, 2020; Wa Viner, Russel, Croker, Packer \& Booy, 2020). A stimulative work atmosphere and positive emotions of students facilitate the achievement of high-quality performance in the learning process and contribute to the development of intrinsic motivation (Heidig, Müller, \& Reichelt, 2015). The epidemic has brought changes in the organization of employees in various fields, including education. The distance learning skills formed will influence the practices of interpersonal communication and relationships (Chiodini, 2020). During this period, the accent falls on the essentialization of information, on self-learning and self-assessment. The process of teaching, providing feedback, monitoring student performance, and individualizing training are more difficult to achieve in the absence of direct contact between students and teachers. The use of new technologies in the distance learning process can be achieved successfully if clear models and instructions are provided, the necessary framework for practising knowledge is created, feedback is given, and special attention is paid to the development of 
students' metacognitive skills (Surma \& Kirschner, 2020). Botnariuc et al. (2020) conducted a study on the optimal conditions in which online learning can be done at the pre-university level, analyzing the opinions of teachers. During the study, a series of recommendations were formulated, both for practitioners and for decision-makers in the field of education. The opinions of all educational actors are important landmarks in optimizing distance learning practices. Recent research has shown that it is necessary to develop teachers' skills in conducting eLearning activities (Schleicher, 2020). In this context, teachers are forced to take creative steps, to improve themselves, and to make efforts to achieve high-quality teaching, even in the absence of all the resources and tools they need. At the level of primary and pre-school education, the role of the teacher is extremely important in order to achieve active and interactive training. In interactive training, the accent falls on collaboration and the learning process is facilitated by interactions between students (Bocoș, 2013). The type of feedback and the frequency with which it is provided influences the success of the teaching-learning processes (Hattie \& Timperley, 2007). Authentic parent-student-teacher communication is a decisive factor for the success of online training processes. The study conducted by Botnariuc et al. (2020) highlighted the fact that students with good and very good learning outcomes perform significantly better than students with bad or very bad learning outcomes, as a result of distance learning activities. Thus, students with bad or very bad learning outcomes have a much lower chance of completing the proposed content and achieving authentic learning. Botnariuc et. al (2020) showed that the background of students is an important factor that can influence the success of educational activities conducted online. Also, in order to get students accustomed to using new technologies, teachers should frequently provide students with work tasks that involve the use of digital resources and equipment. Adaptive e-learning facilitates the achievement of educational goals and has a high degree of attractiveness for primary school students (Hubalovsky, Hubalovska, \& Musilek, 2019). In general, the judicious use of digital resources in primary education can ensure the success of learning situations.

In online learning sessions, it is difficult to provide personalized support to students, and differentiated training has suffered greatly. "The lack of opportunities for personalized support for students with special learning needs is signaled by teachers in all cycles of education, being a significantly bigger problem for primary school teachers" (Botnariuc et al., 2020). Also, monitoring the individual progress made by students in the learning process is an extremely difficult step to achieve (Botnariuc et al., 2020). Asynchronous 
communication methods have been used frequently by most primary school teachers. The study revealed that the phenomenon of bullying has been diminished in the absence of direct interactions between students, but there are situations in which it persists in the online environment.

\section{RESEARCH METHODOLOGY}

For this research, a questionnaire consisting of 12 questions was developed, through which we aimed at collecting data on various aspects of the distance learning processes occurring in primary education (see Appendix A). The questionnaire was completed online between March and May 2020 by 1456 parents (see Tables 1 and 2). Most respondents have children enrolled in the third grade (369 of them) (see figure 1). The average age of the participants is 37.9 years.

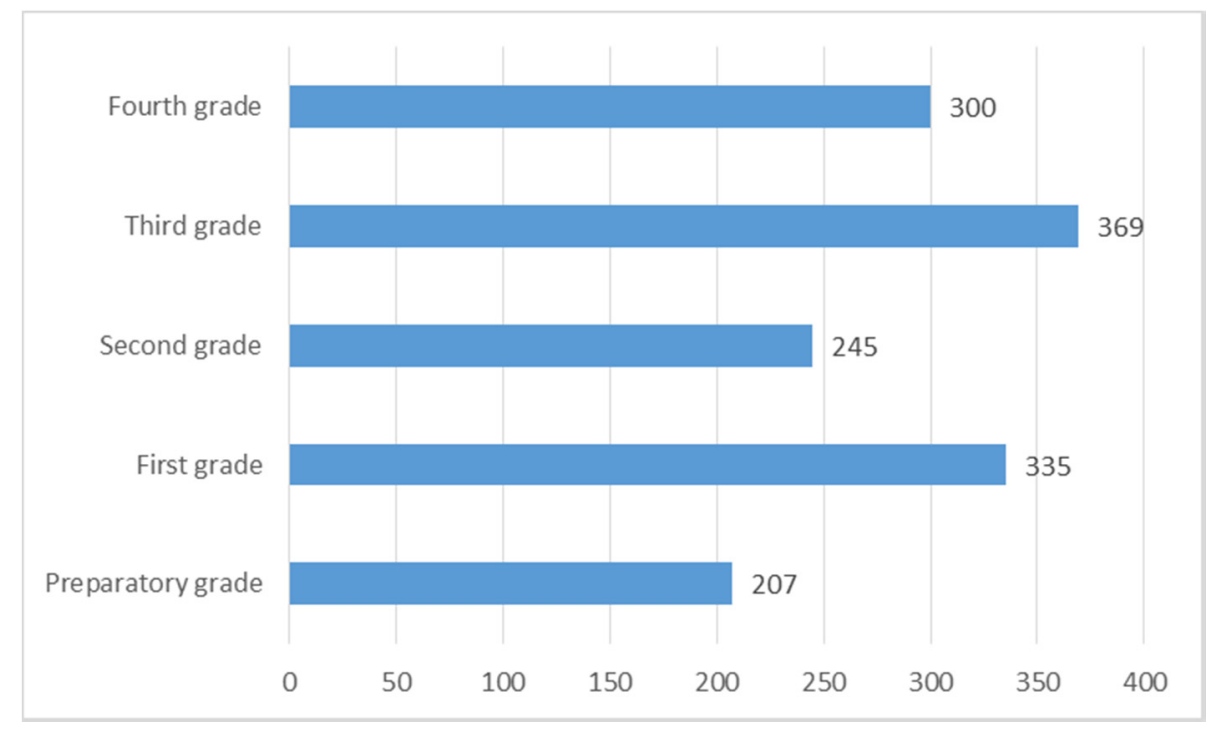

Figure 1. Distribution of the sample of participants, taking into account the age of the pupils 
Table 1. Distribution of the sample of participants, depending on the gender variable

\begin{tabular}{lcc}
\hline \multicolumn{1}{c}{ Gender } & Frequency & Percentage \\
\hline Female & 1270 & $87.22 \%$ \\
Male & 186 & $12.77 \%$ \\
\hline
\end{tabular}

Table 2. Distribution of the sample of participants, taking into account the place of residence of the participants

\begin{tabular}{lcc}
\hline $\begin{array}{c}\text { Place of } \\
\text { residence }\end{array}$ & Frequency & Percentage \\
\hline Rural & 215 & $14.77 \%$ \\
Urban & 1241 & $85.23 \%$ \\
\hline
\end{tabular}

\section{Results}

Most respondents (both urban and rural) appreciated that in the context of online lessons, their children cannot manage on their own without asking for help from other family members (see Figure 2 and Table 3).

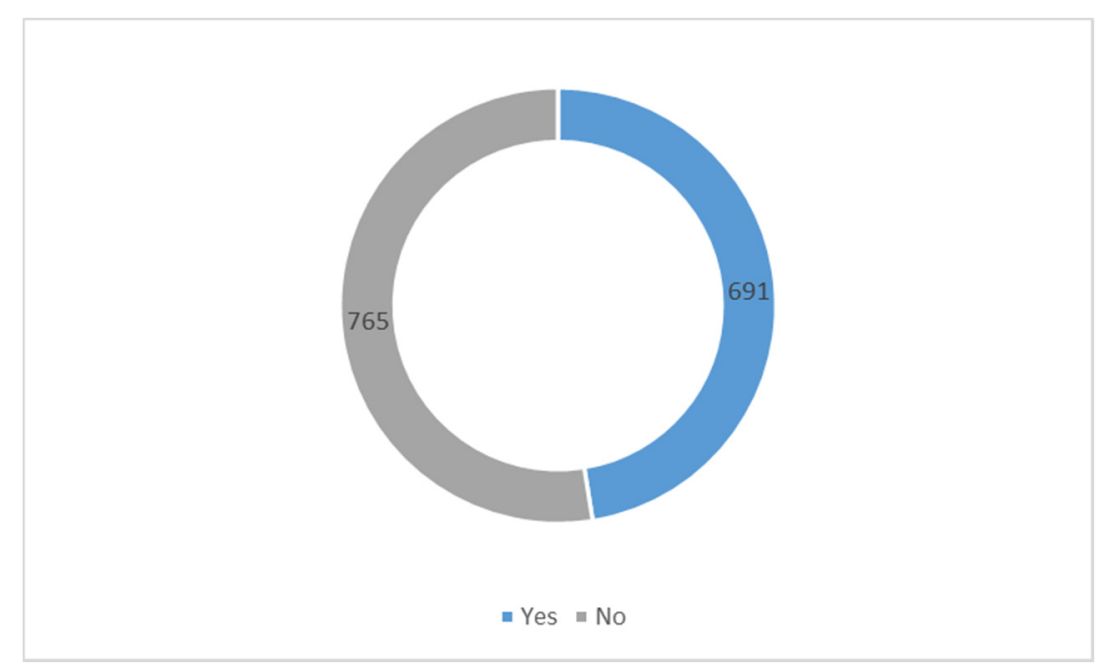

Figure 2. Aspects related to the degree of independence of students in the learning activity 
Table 3. The degree of independence of students in the learning activity, taking into account the residence of the students

\begin{tabular}{lllll}
\hline Answer variant & \multicolumn{3}{c}{ Place of residence } \\
& \multicolumn{3}{c}{ Rural } & \multicolumn{2}{c}{ Urban } \\
& Frequency & Percentage & Frequency & Percentage \\
\hline Yes & 108 & $50.23 \%$ & 657 & $52.94 \%$ \\
No & 107 & $49.77 \%$ & 584 & $47.06 \%$ \\
\hline
\end{tabular}

Most respondents believe that the purpose of student-teacher interactions should be to recapitulate and consolidate knowledge and maintain a close link with students and their families (see Figure 3 and Table 4).

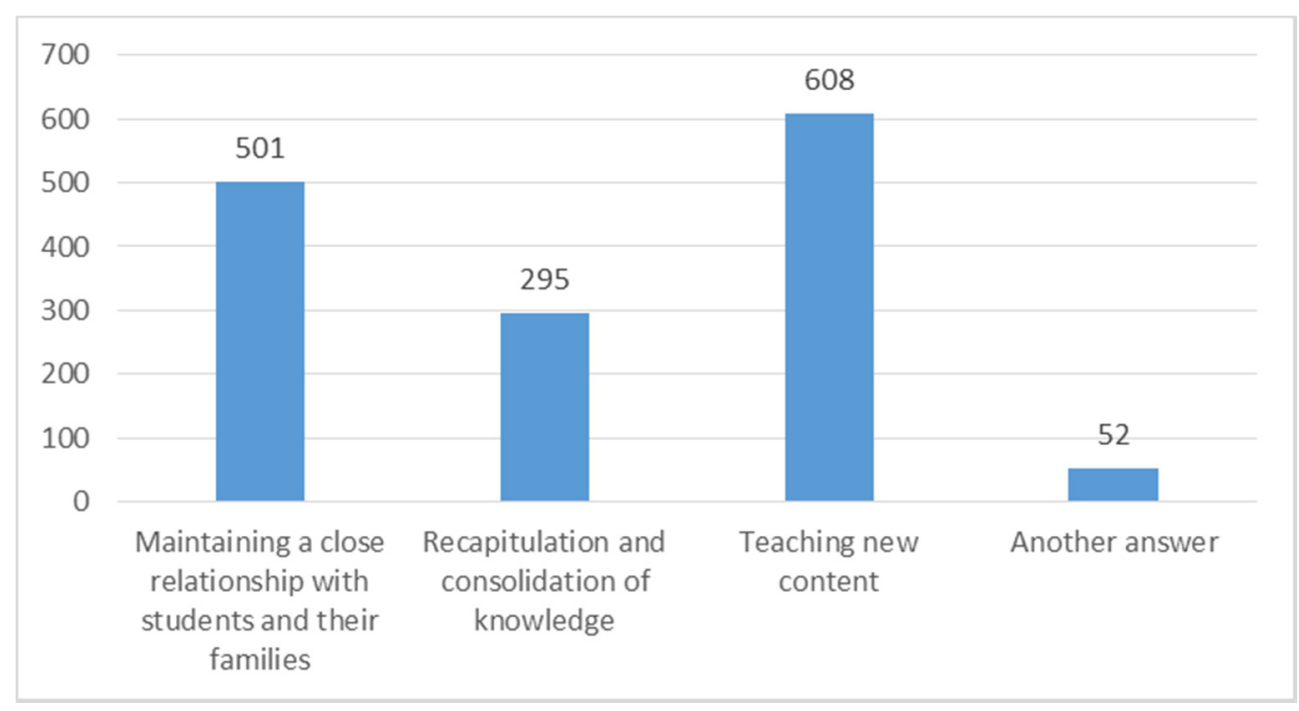

Figure 3. Aspects regarding the finality of the interactions between students and teachers 
Table 4. Parents' opinions regarding the finality of the interactions between parents and students, taking into account the place of residence of the respondents

\begin{tabular}{lcccc}
\hline \multirow{2}{*}{ Answer variant } & \multicolumn{4}{c}{ Place of residence } \\
\cline { 2 - 5 } & Frequency & Percentage & Frequency & Percentage \\
\hline $\begin{array}{l}\text { Maintaining a } \\
\text { close relationship } \\
\begin{array}{l}\text { with students and } \\
\text { their families }\end{array}\end{array}$ & 99 & $46.04 \%$ & 402 & $32.39 \%$ \\
$\begin{array}{l}\text { Recapitulation } \\
\text { and consolidation } \\
\text { of knowledge }\end{array}$ & 82 & $38.14 \%$ & 213 & $17.16 \%$ \\
$\begin{array}{l}\text { Teaching new } \\
\text { content }\end{array}$ & 31 & $14.42 \%$ & 577 & $46.49 \%$ \\
Another answer & 3 & $1.4 \%$ & 49 & $3.95 \%$ \\
\hline
\end{tabular}

The respondents who chose another answer had different opinions regarding the organization of the instructive-educational process during this period. Some of them selected all the predefined answer options (27 respondents), while others chose various combinations of them (9 of the parents). Some respondents wanted the primary school teacher to make efforts to convey well-structured and understandable information to students, to create the conditions to increase their motivation to learn and to actively contribute to strengthening the emotional relationship between students and teachers. From the perspective of these parents, the lessons must be interactive and allow for feedback. Some respondents also specified that distance learning processes should be designed to help students to complete school activities frequently, to adapt more easily to the demands of school life after the resumption of classes. In the opinion of other respondents, these learning activities are not effective and should not be organized (4 respondents).

The modalities used to communicate with teachers are varied (see Figure 4). The most commonly used is the WhatsApp instant messaging network (786 respondents). Also, school-family communication is achieved through telephone calls (11 respondents) and e-mail (16 respondents). 


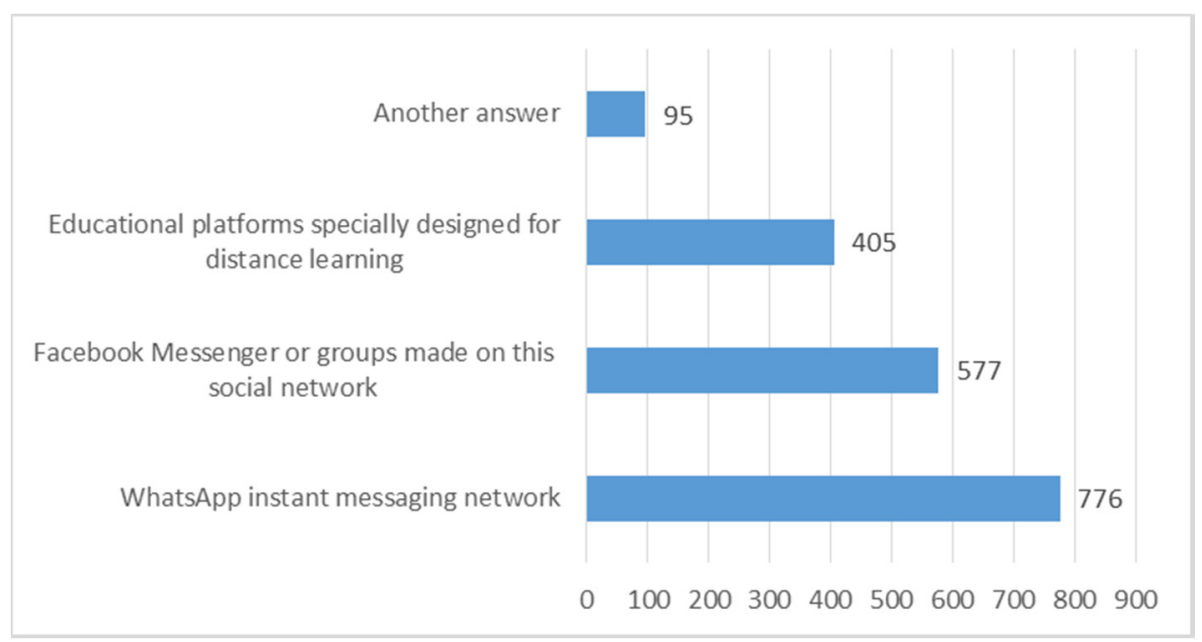

Figure 4. Ways of school-family communication, during the epidemic

From the perspective of most parents, the learning materials provided by teachers have a medium or low degree of difficulty (see Figure 5).

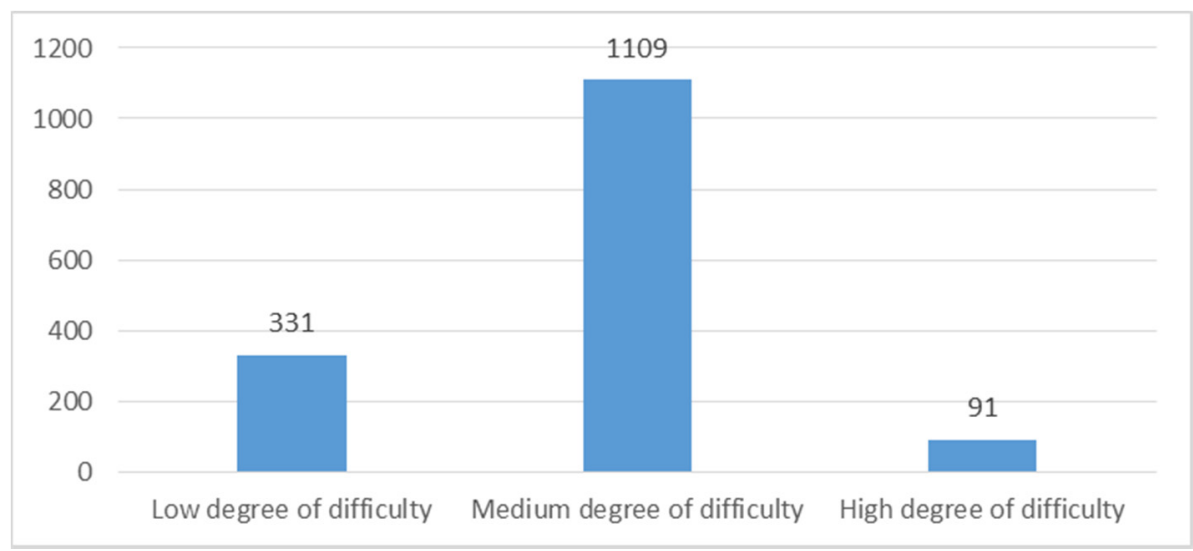

Figure 5. The degree of difficulty of learning tasks, from the perspective of students and parents

If some students received feedback several times a week, daily or several times a day, there are situations in which students did not receive or only rarely received feedback from teachers (see Figure 6). 
Parents mentioned that effective feedback was provided especially during online meetings, through a video conferencing system.

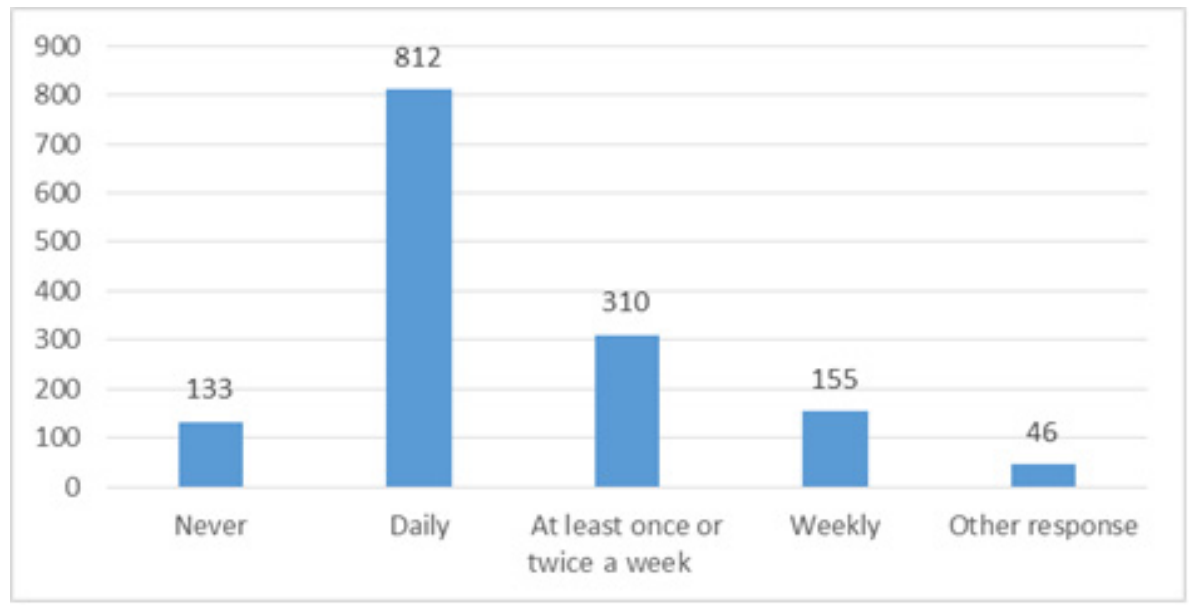

Figure 6. The frequency with which students receive feedback

Most students spend 1-2 hours in front of the computer, tablet, or other electronic devices with visual display, to carry out learning activities (see Figure 7 and Table 5).

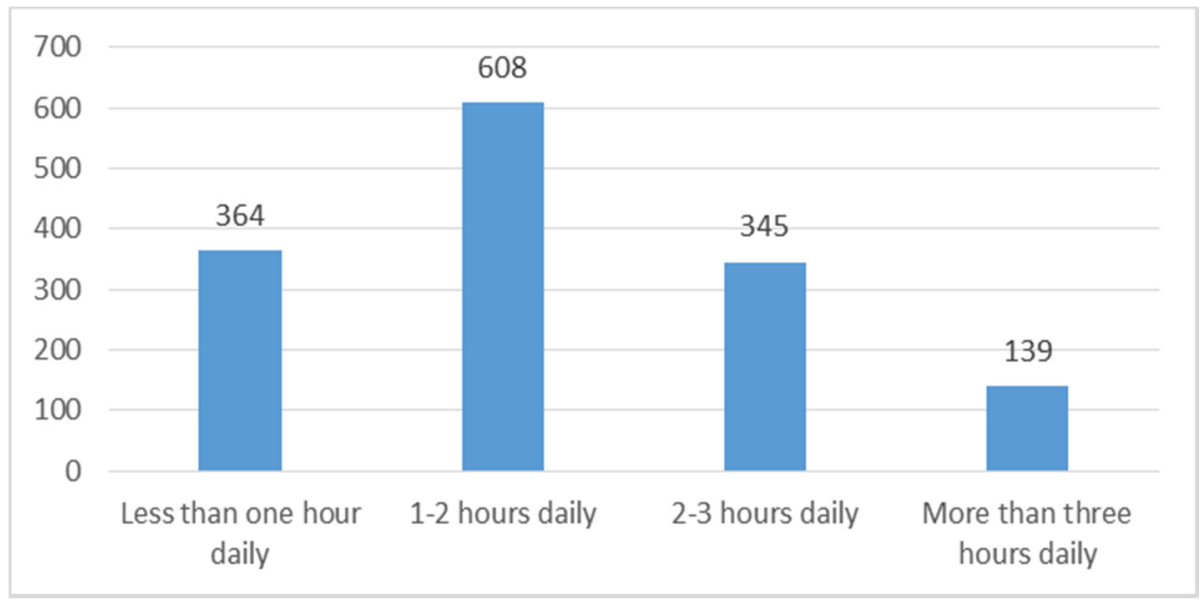

Figure 7. Duration of activities performed using electronic devices with visual display 
Table 5. The amount of time allocated to the use of new technologies, taking into account the students' place of residence

\begin{tabular}{lcccc}
\hline \multirow{2}{*}{ Answer variant } & \multicolumn{4}{c}{ Place of residence } \\
\cline { 2 - 5 } & \multicolumn{3}{c}{ Rural } & \multicolumn{2}{c}{ Urban } \\
& Frequency & Percentage & Frequency & Percentage \\
\hline Less than an hour & 48 & $22.33 \%$ & 316 & $25.46 \%$ \\
$\begin{array}{l}\text { a day } \\
\text { 1-2 hours a day }\end{array}$ & 108 & $50.23 \%$ & 500 & $40.29 \%$ \\
2-3 hours a day & 46 & $21.4 \%$ & 299 & $24.09 \%$ \\
More than 3 & 13 & $6.05 \%$ & 126 & $10.15 \%$ \\
hours a day & & & & \\
\hline
\end{tabular}

The most common problems encountered by students in the learning process are an insufficient level of development of digital skills, lack of internet access or connection problems, lack of a computer, tablet or a high-performance phone, technical difficulties in connecting on certain platforms, as well as emotional problems, closely related to the sudden suspension of pre-university education courses or to the evolution of the current epidemiological context (see Figure 8 and Table 6).

Other problems encountered by students and parents are:

- the inefficiency of student-teacher communication, due to inadequate intervention of colleagues or parents;

- the absence of adults to guide them to access learning platforms or to solve work tasks;

- the absence of the learning environment in the classroom and the physical contact with the other colleagues and, in particular, with the teacher, to whom the students are very emotionally connected;

- the need to spend a long time in front of electronic devices or to solve the tasks assigned by teachers, which they find difficult to perform and are sometimes more numerous than before the suspension of classes;

- a large amount of information that needs to be transmitted;

- the long period of time needed to solve learning tasks; 


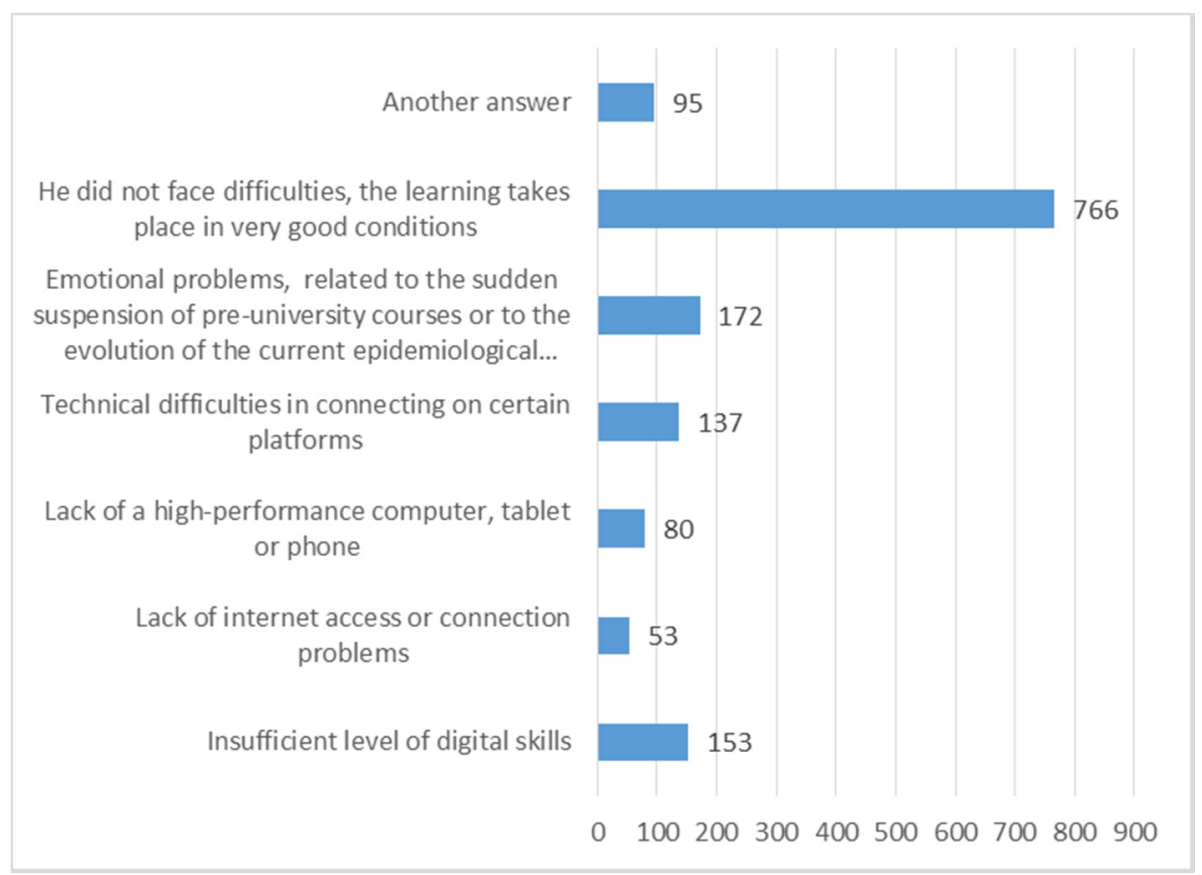

Figure 8. Factors that affect the quality of students' learning processes

- lack of motivation for learning and the need for immediate feedback provided by the teacher;

- insufficiently developed computer skills or use of the equipment and applications needed to undergo the learning process;

- low ability to adapt to the specifics of new learning situations in the online environment;

- lack of high-performance equipment for carrying out these activities;

- emotional problems, arising after the beginning of the epidemic;

- difficulties in understanding the information transmitted, if it is not explained by the teacher through online interactions;

- using the equipment for other types of activities, which are not related to the learning activity, among which we mention: computer games, conversations with colleagues, watching videos on the internet, etc.; 
- the decrease in motivation for learning, by considering the period of suspension of courses as a holiday;

- the absence of parents' teaching skills, if their intervention is necessary; learning;

- problems related to the organization of the time allocated to

- children's belonging to large or single-parent families;

- the absence of interactive training, if learning platforms that involve systematic interactions between teachers and students are not used.

Table 6. Problems encountered by students, taking into account the place of residence

\begin{tabular}{lcccc}
\hline \multicolumn{1}{c}{ Answer variant } & \multicolumn{4}{c}{ Place of residence } \\
\cline { 2 - 5 } & \multicolumn{3}{c}{ Rural } & \multicolumn{2}{c}{ Urban } \\
\cline { 2 - 4 } & Frequency & Percentage & Frequency & Percentage \\
\hline $\begin{array}{l}\text { Insufficient level of } \\
\text { digital skills }\end{array}$ & 18 & $8.37 \%$ & 135 & $10.88 \%$ \\
$\begin{array}{l}\text { Lack of internet access } \\
\text { or connection problems }\end{array}$ & 17 & $7.91 \%$ & 36 & $2.9 \%$ \\
$\begin{array}{l}\text { Lack of a high- } \\
\text { performance computer, } \\
\text { tablet or phone }\end{array}$ & 15 & $6.98 \%$ & 65 & $5.24 \%$ \\
$\begin{array}{l}\text { Technical difficulties in } \\
\text { connecting on certain } \\
\text { platforms }\end{array}$ & 23 & & & \\
$\begin{array}{l}\text { Emotional problems, } \\
\text { related to the sudden }\end{array}$ & 24 & $10.7 \%$ & 114 & $9.19 \%$ \\
$\begin{array}{l}\text { suspension of pre- } \\
\text { university courses or to } \\
\text { the evolution of the } \\
\text { current epidemiological } \\
\text { context }\end{array}$ & & & & \\
\hline
\end{tabular}


Parents mentioned that the need to accumulate too much information and the long time needed to complete homework can lead to emotional problems among children. Parents of students in the preparatory class pointed out that at this age it is difficult to adjust to distance learning situations, given that they have barely managed to adapt to school requirements. Some parents have shown that although they are making efforts to help their children with their work tasks, they do not have the necessary skills. Thus, some respondents pointed out that there is a decrease in the quality of teaching, and sometimes a decrease in the frequency of positive and high-quality learning experiences. Most of the respondents did not encounter any problems in their learning activity (789 students, of which 114 come from rural areas).

Regarding the level of motivation for students' learning, most parents appreciated that students' interest in learning activities decreased in the context of participating in distance learning (see Figure 9 and Table 7).

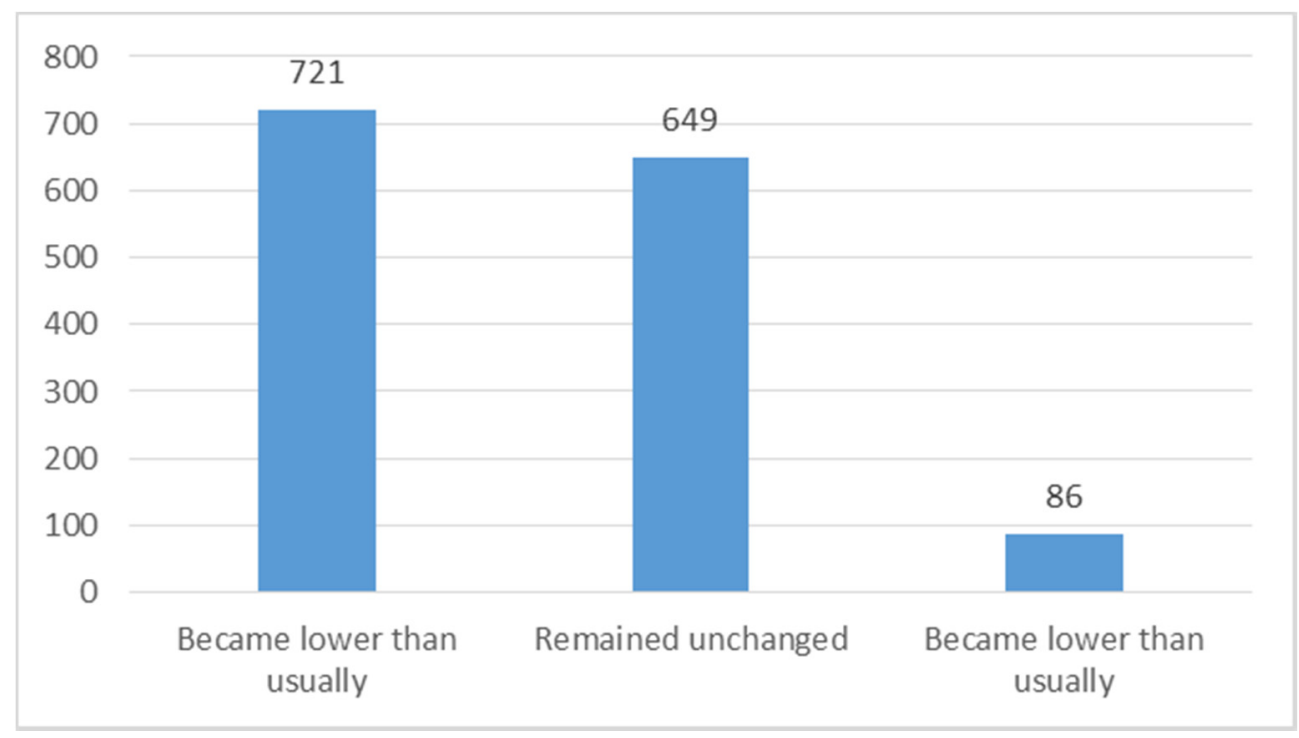

Figure 9. Level of students' motivation for learning 
Table 7. Information on the level of motivation for learning, taking into account the place of residence of the students

\begin{tabular}{lcccc}
\hline \multirow{2}{*}{ Answer variant } & \multicolumn{4}{c}{ Place of residence } \\
\cline { 2 - 5 } & Frequency & Percentage & Frequency & Percentage \\
\hline $\begin{array}{l}\text { Became lower } \\
\text { than usual }\end{array}$ & 108 & $50.23 \%$ & 613 & $49.4 \%$ \\
$\begin{array}{l}\text { Remained } \\
\text { unchanged }\end{array}$ & 93 & $43.26 \%$ & 556 & $44.8 \%$ \\
$\begin{array}{l}\text { Became lower } \\
\text { than usually }\end{array}$ & 14 & $6.51 \%$ & 72 & $5.8 \%$ \\
\hline
\end{tabular}

A large part of the students (38.8\% of them) do not want the distance learning activities to take place even occasionally after starting school, although they like to participate on them at this moment. Most respondents are happy to participate in this type of activity, but there is a high percentage of students who do not like to carry out online activities $(22.2 \%$ of them). Some of the parents who chose the option "Another answer" specified that their son/daughter had not participated in online learning situations until the date they submitted the answers, but consider it beneficial and want them to be organized in this period. Other parents mentioned that the family members have the responsibility of teaching, using the materials sent by the teacher, an approach that they consider extremely difficult. Many of the parents stated that the students prefer the lessons organized in the school space and that the teachers are the ones who have the necessary skills to transmit knowledge and to form skills. Also, students' attention, interest, and motivation for learning are maintained at a high level in the context of face-to-face learning activities. For emotional students, the novelty of these lessons and the new way of interacting with students is more difficult to achieve. Presence in the school environment and direct contact with students and teachers are factors that contribute significantly to the success of learning processes at this level of education. Parents believe that in online interactions, various factors may arise that disrupt the progress of lessons (including 
technical problems, difficulties in using educational platforms, the absence of an adult to supervise them, etc.). Other parents showed that the main advantage of organizing these lessons is the simultaneous and real-time interaction with other colleagues and the teacher, students feeling, both during this period and during the summer vacation, the absence of colleagues and teachers. Other respondents mentioned that in the absence of assessment and feedback, students are not aware of the need for learning and do not take this process seriously. Also, in the opinion of some parents, the homework offered to students during this period consists of a large number of exercises, which require the allocation of a long period of time. Thus, in the context in which parents currently assume a large number of family and professional responsibilities, it is difficult to effectively organize their time to carry out these learning activities. Also, some students spend a lot of time in front of electronic devices with visual display, which has a negative impact on their health. Some students did not have access to this type of learning, although they would have liked to, because they do not have the necessary equipment to carry out, in good conditions, distance learning activities (see Figure 10).

From the perspective of most parents, schools should implement health education programs, which include information and educational counseling activities for students, both during the suspension of classes and immediately after the end of the epidemic (see Figure 11 and Table 7). A low percentage of parents do not want these programs to take place in our country. Also, most parents who chose the option "Another answer" showed that these health programs should have been implemented long ago in schools in Romania. Thus, the respondents pointed out that in preuniversity education, effectively implemented health education programs should be permanently organized and should include both activities with students and parents. Other respondents pointed out that health education activities are organized systematically or occasionally in schools, through the contents included in the compulsory or optional subjects, as well as in the extracurricular activities. Also, some parents pointed out that health education programs should not include content related to sex education. Also, in the opinion of parents, it would be necessary that school counselors and medical staff to participate in activities. 


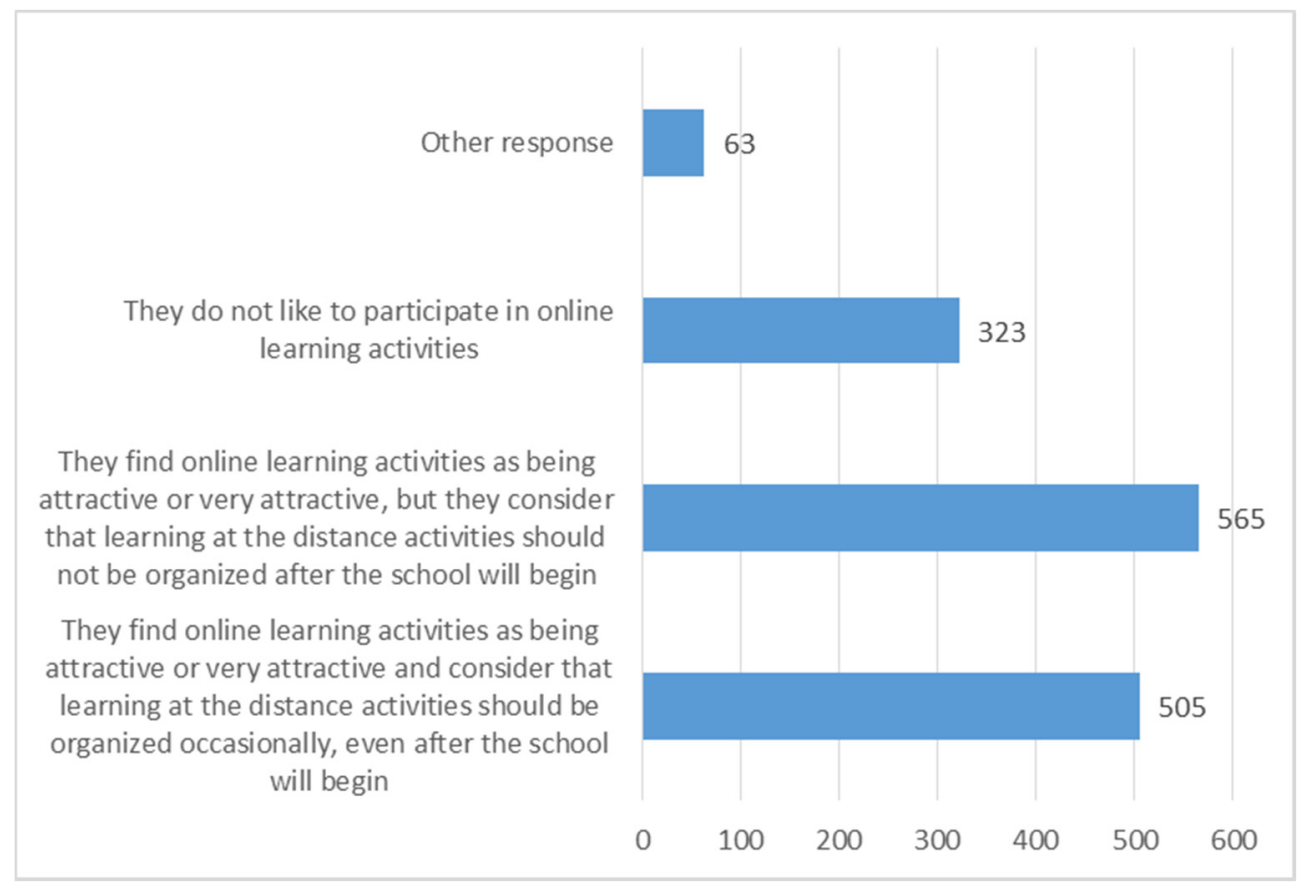

Figure 10. The degree of attractiveness of the activities carried out in the online environment and the frequency with which they should be organized

Regarding the frequency with which the activities included in the health education programs should be carried out, some of the parents indicated that it would be ideal for them to take place monthly or weekly, throughout schooling. Other respondents pointed out that health education programs should be carried out after school starts, given that during this period the media provide sufficient information for students and parents on how students should behave during this epidemic. Thus, the advice and guidance provided by parents are sufficient for students to adopt a preventive and healthy behavior during the epidemic. 


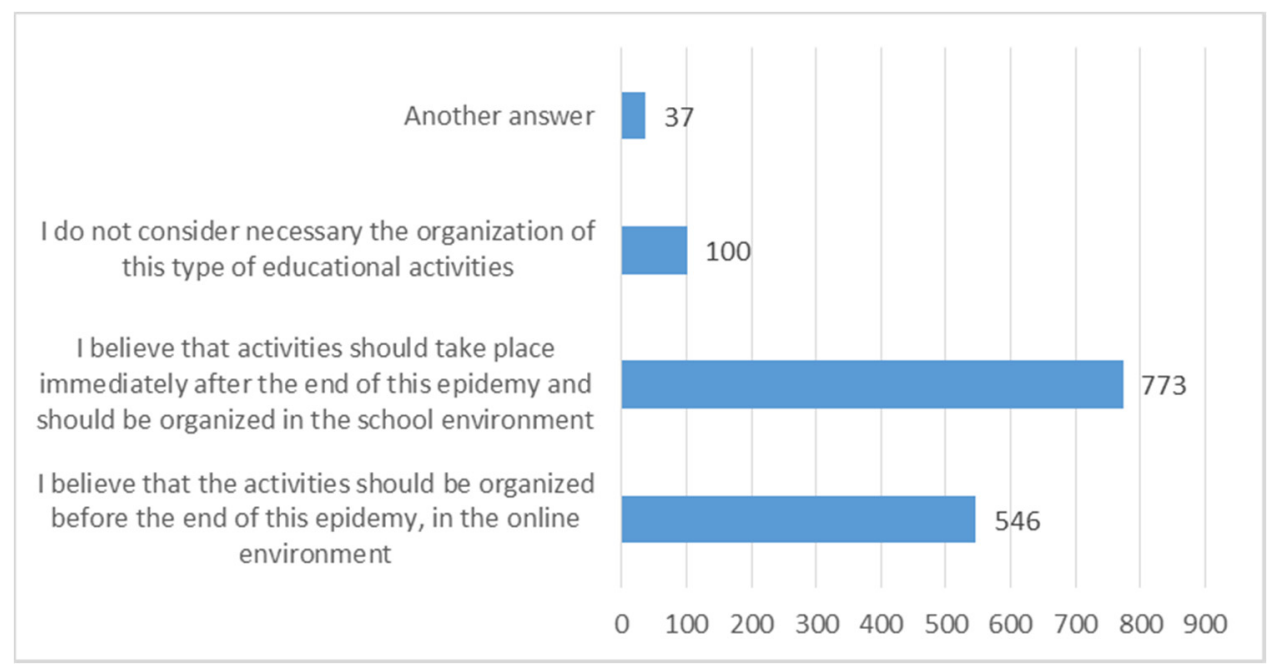

Figure 11. Respondents' opinion regarding the implementation of the health education programs

Table 8. Respondents' opinion regarding the implementation of the health education programs

\begin{tabular}{l|cccc}
\hline \multicolumn{1}{c}{ Answer variant } & \multicolumn{3}{c}{ Place of residence } \\
\cline { 2 - 5 } & \multicolumn{3}{c}{$\begin{array}{c}\text { Rural } \\
\text { Frequency }\end{array}$} & $\begin{array}{c}\text { Percentage } \\
\text { Frequency Percentage }\end{array}$ \\
\hline $\begin{array}{l}\text { I believe that the activities } \\
\text { should be organized before } \\
\text { the end of this epidemy, in the } \\
\text { online environment }\end{array}$ & 85 & $39.53 \%$ & 461 & $37.15 \%$ \\
& & & & \\
$\begin{array}{l}\text { I believe that activities should } \\
\text { take place immediately after } \\
\text { the end of this epidemy and } \\
\text { should be organized in the } \\
\text { school environment }\end{array}$ & 111 & $51.63 \%$ & 662 & $53.34 \%$ \\
$\begin{array}{l}\text { I do not consider necessary } \\
\text { the organization of this type } \\
\text { of educational activities }\end{array}$ & 114 & & & \\
\hline
\end{tabular}


Most parents agreed that if there will be an extended period of suspension of courses, the recovery of untaught contents in this school year should be achieved either through online activities or in the next school year, within face-to-face learning activities.

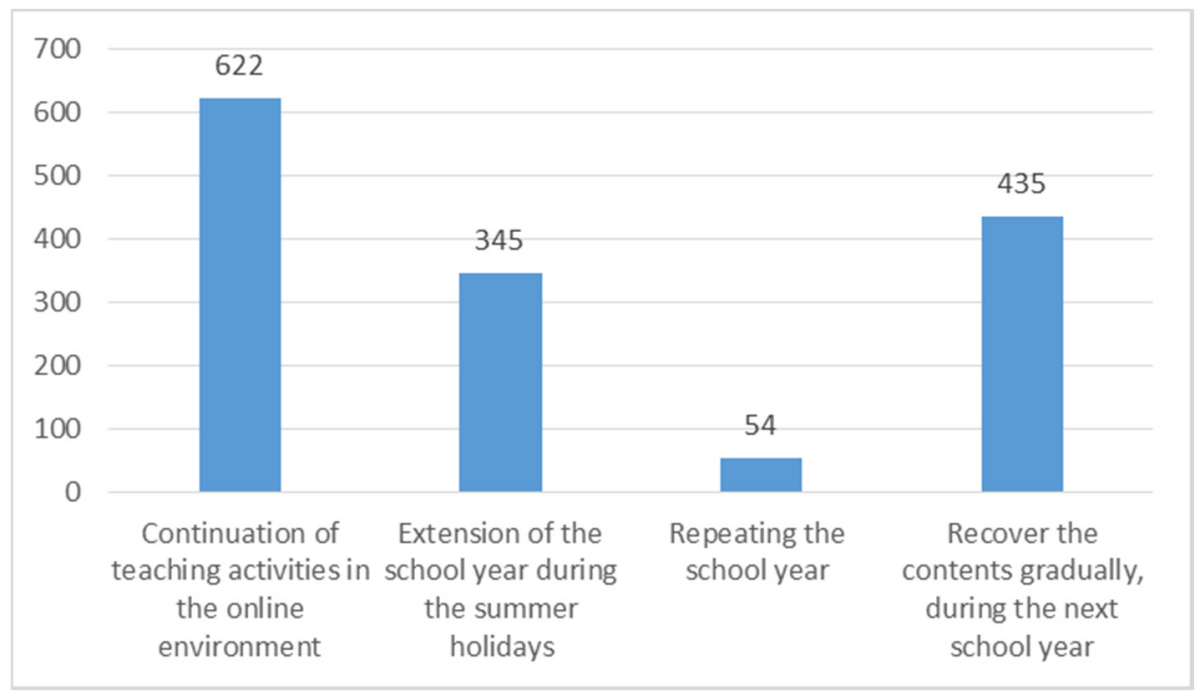

Figure 12. Solutions proposed by parents for the optimal recovery of untreated matter

Some parents consider that, in primary education, teaching is very difficult to be realized in the online environment and do not want students to participate in this type of activity. Some of them also pointed out that the level of motivation for learning has become lower during this period, and some learning tasks and contents have a high degree of difficulty. Some respondents mentioned that students are too young to participate in online lessons, that they do not have the necessary skills to participate in distance learning activities, and that the pressure on students and parents is high and unnecessary. The fact that teacherstudent interactions take place in the virtual space negatively influences the quality of the teaching act. One of the parents mentioned that this period of suspension of courses could have been used by employees in 
the field of education to restructure and simplify the content of school curricula, as well as to create high-quality teaching materials, accessible for free to students and parents.

\section{Discussions and Conclusions}

Among the limitations of the current study, we can mention the small size of the sample of participants and the origin of most of them from a single county in Romania, which cannot ensure national representation. The study could also have focused on the opinions of educational managers and teachers, to help us form an overview of the educational realities investigated. Based on the results obtained, a series of recommendations can be formulated for primary school practitioners:

- clear formulation of work tasks, monitoring progress in learning and systematically providing positive and constructive feedback;

- designing high-quality and attractive teaching materials for students;

- achieving the didactic transposition at a high-quality level, when new notions are taught;

- maintaining a close connection with parents and students, with the purpose to strengthen the school-family partnership relationship and the student-teacher relationship.

Analyzing the opinions of the parents, the following recommendations can be formulated for the decision-makers in the educational field:

- creating educational resources, software and functional educational platforms, free and easy to use by teachers and students in primary education;

- restructuring the contents included in the school curricula, with the purpose of making them more accessible;

- significant investments in technological equipment and training programs for teachers;

- developing a long-term strategy, based on recommendations made by researchers, practitioners, and expert groups in the field of education. 
It is important to note that this questionnaire was distributed online and was completed by parents who have access to the internet. The media revealed that there are a large number of students from disadvantaged backgrounds who do not have the opportunity to do online learning activities. For these students, a period of remedial education should be established in the next school year. Teachers who teach in primary education have had to find innovative solutions to support these students and ensure them equal opportunities and access to education. Investing in digital resources and equipment, obtaining sponsorships, and entering into partnerships with IT companies are some of the measures that should be taken. Research should be continued after the pandemic to correct possible dysfunctions of the teaching processes and to capitalize on the positive aspects that have occurred in the teaching activity.

\section{Acknowledgements}

Participation was possible with the financial support of the Operational Programme Human Capital 2014-2020, under the project number POCU 123793 with the title "Researcher, future entrepreneur New Generation". We are also deeply grateful to all the parents who participated in this study.

\section{REFERENCES}

Adams, K.S., \& Christenson, S.L. (2000). Trust and the family-school relationship: Examination of parent-teacher differences in elementary and secondary grades. Journal of School Psychology, 38, 477-497.

Addi-Raccach, A., \& Arviv-Elyashiv, R. (2008). Parent empowerment and teacher professionalism - teachers' perspectives. Urban Education, 43(3), 394-415.

Bocoș, M.-D. (2013). Instruirea interactivă. Repere axiologice și metodologice. Iași: Editura Polirom. 
Botnariuc, P., Cucoș, C., Glava, C., Iancu, D.-E., Ilie, M.D., Istrate, O., Labăr, A.V., Pânișoară I.-O., Ștefănescu, V., \& Velea, S. (2020) Școala online. Elemente pentru inovarea educației. Raport de cercetare evaluativă. București, Editura Universității din București, available at https://unibuc.ro/wpcontent/uploads/2020/05/Scoala_Online_Raport_aprilie_2020.pdf?fbclid=I wAR3v2R9E4xOVnIwZIIPcPLcHwqt6ijrbAuCRY5 w7LumkrbVwurImvSIRpic.

Cakiroglu, A., \& Kuruyer, H.G. (2012). First grade elementary school student's family involvement. Procedia - Social and Behavioral Sciences, 46, 55885592.

Chiodini, J. (2020). Online learning in the time of COVID-19. Travel Medicine and Infectious Disease, 34.

Cankar, F., Deutsch, T., \& Kolar., M. (2009). Teachers and Parents- Partners with Different Expectations. International Journal about Parents in Education, 3(1), 15-28.

Cox, D.D. (2005). Evidence-based interventions using home-school collaboration. School Psychology Quarterly, 20, 473-497.

Crozier, G. (1999). Is it a case of "we know when we're not wanted"? The parents' perspective on parent-teacher roles and relationships. Educational Research, 41(3), 315-328.

Culp, R.E., Schadle, S., Robinson, L., \& Culp, A.M. (2000). Relationships among parental involvement and young children`s perceived self-competence and behavioral problems. Journal of Child and Family Studies, 9(1), 27-38.

Eames, K.., Tilston, N. L., White, P.J., Adams, E., \& Edmunds, W.J. (2010). The impact of illness and the impact of school closure on social contact patterns. Retrieved from https://www.journalslibrary.nihr.ac.uk/hta/hta1434004/\#/abstract.

Epstein, J.L. (2001). School, family, and community partnerships: Preparing educators and improving schools. Boulder, CO: Westview Press.

Favale, T., Soro, F., Trevisan, M., Drago, I., \& Mellia, M. (2020, May 8). Campus traffic and e-Learning during COVID-19 pandemic. Retrieved from https://arxiv.org/abs/2004.13569.

Greenwood, G.E., \& Hickman, C.W. (1991). Research and practice in parent involvement: Implications for teacher education. The Elementary School Journal, 91, 279-288.

Griebler, U., Rojatz, D., Simovska, V., \& Forster, R. (2014). Effects of student participation in school health promotion: a systematic review. Health Promotion International, 32(2), 195-206. 
Grolnick, W.S., Benjet, C., Kurowski, C.O., \& Apostoleris, N.H. (1997). Predictors of parent involvement in children's schooling. Journal of Educational Psychology, 89(3), 538-548.

Guerra, M., \& Luciano, E. (2010). Sharing the responsibility of education: The relationship between teachers and parents in 0-6 year-old children services and schools. Procedia - Social and Behavioral Sciences, 2(2), 3308-3313.

Hattie, J., \& Timperley, H. (2007). The power of feedback. Review of Educational Research, 77(1), 81-112. https://doi.org/10.3102/003465430298487.

Heidig, S., Müller, J., \& Reichelt, M. (2015). Emotional design in multimedia learning: Differentiation on relevant design features and their effects on emotions and learning. Computers in Human Behavior, 44, 81-95. https://doi.org/10.1016/j. chb.2014.11.009

Hill, N.E., \& Taylor, L.C. (2004). Parental school involvement and children's academic achievement: Pragmatics and issues. Current Directions in Psychological Science, 13, 161-164.

Hubalovsky, S., Hubalovska, M., \& Musilek, M. (2019). Assessment of the influence of adaptive E-learning on learning effectiveness of primary school pupils. Computers in Human Behavior, 92, 691-705. https://doi.org/10.1016/j.chb.2018.05.033.

Izzo, C.V., Weissberg, R.P., Kasprow, W.J., \& Fendrich, M. (1999). A longitudinal assessment of teacher perceptions of parental involvement in children's education and school performance. American Journal of Community Psychology, 27, 817- 839.

Lazar, A., \& Slostad, F. (1999). How to overcome obstacles to parent-teacher partnerships. The Clearing House, 72(4), 206-210.

Lee, A., Lo, A. S.C., Keung, M.V., Kwong, C.M.A., \& Wong, K.K. (2019). Effective health promoting school for better health of children and adolescents: indicators for success, BMC Public Health, 19, 1-12.

Lister-Sharp, D., Chapman, S., Stewart-Brown, S., \& Sowden, A. (1993). Health promoting schools and health promotion in schools: two systematic reviews. Health Technology Assessment, 3, 1-201.

Pavalache-Ilie, M., \& Țîrdia, F.-A. (2015). Parental Involvement and Intrinsic Motivation with Primary School Students. Procedia - Social and Behavioral Sciences, 187, 607-612.

Powell, D.R., Son, S., File, N., \& San Juan, R. R. (2010). Parent-school relationships and children's academic and social outcomes in public school prekindergarten. Journal of School Psychology, 48(4), 269-292. 
Prime, H., Wade, M., \& Browne, D.T. (2020). Risk and resilience in family wellbeing during the COVID-19 pandemic. American Psychologist. Advance online publication. http://dx.doi.org/10.1037/amp0000660.

Samdal, O., \& Rowling, L. (2011). Theoretical and empirical base for implementation for health-promoting schools. Health Education, 111(5), 367-90.

Horesh, D., \& Brown, A.D. (2020). Traumatic stress in the age of COVID-19: A call to close critical gaps and adapt to new realities. Psychological Trauma: Theory, Research, Practice, and Policy, 12(4), 331-335. http://dx.doi.org/ 10.1037/tra0000592.

Schleicher, A. (2020). How can teachers and school systems respond to the COVID19 pandemic? Some lessons from TALIS. OECD Forum, 23 March 2020. Retrieved from https://www.oecd-forum.org/users/50583-andreasschleicher/ posts/63740-how-can-teachers-and-school-systems-respond-to-the-covid19-pandemic-some -lessons-from-talis.

Schober, B., \& Spiel, C. (2008). Time students spend working at home for school, Learning and Instruction, 18(4), 309-320.

Sheldon, S. (2003). Linking school-family-community partnerships in urban elementary schools to student achievement on state tests. The Urban Review, 35(2), 140-166.

Surma, T., \& Kirschner, P.A. (2020). Technology enhanced distance learning should not forget how learning happens. Retrieved from https://reader.elsevier.com/ reader $/ \mathrm{sd} / \mathrm{pii} /$ S0747563220301436?token $=1 B A 61334$ CF0FACE991A73D 5F82164FDC869310EF992F4F4EB4B30EC0446E87EC1AEC6030C77856C F5FC96607B06FC02D.

Swick, K.J. (2003). Communication concepts for strengthening Family-SchoolCommunity partnerships. Early Childhood Education Journal, 30(4), 275280.

Trung, T., Hoang, A. -D., Nguyen, T.T., Dinh, V.-H., \& Pham, H.-H. (2020, June). Dataset of Vietnamese student's learning habits during COVID-19. Retrieved from https://arxiv.org/abs/2004.13569.

Wa Viner, M.R., Russel, J.S., Croker, H., Packer, J., \& Booy, R. (2020, May 5). School closure and management practices during coronavirus outbreaks including COVID-19: a rapid systematic review. Retrieved from https://www.thelancet.com/journals/lanchi/article/PIIS2352-4642(20) 30095-X/fulltext 


\section{PARENTS' OPINION REGARDING THE USE OF DISTANCE LEARNING \\ DURING COVID-19 PANDEMIC}

\section{Appendix A}

\section{Questionnaire regarding the use of distance learning in primary education}

Through this study, we aim to investigate the opinion of parents on the optimal solutions that can be applied to optimize the distance learning processes, currently carried out by primary school students. Completing this questionnaire takes a maximum of 5 minutes, and the answers will remain anonymous. Your opinions will be useful to decision-makers in the field of education and primary school teachers. The data collected will be statistically processed.

\section{What grade does your child attend?}

Preparatory grade

1st grade

2nd grade

3rd grade

4th grade

2. In the context of online learning, can your child manage on his or her own without asking for help from other family members?

Yes

No

3. What do you think should be the purpose of online interactions between students and teachers?

Maintaining a close relationship with students and their families

Teaching new content

Recapitulation and consolidation of knowledge

Another answer option, namely:

4. What form of communication do you use to communicate during this time with your child's teacher? (more answers are possible)

WhatsApp instant messaging network

Facebook Messenger or different groups created on this social network

Educational platforms specially designed for distance learning

Another answer option such as: 
5. Which are the characteristics of learning materials provided by teachers? (more answers are possible)

They have a low degree of difficulty

They have a medium degree of difficulty

They have a high degree of difficulty

\section{How often do students receive feedback from teachers regarding how} homework was done?

Never

Daily

At least once or twice a week

Weekly

$\ulcorner$ Another answer option such as:

7. How much time does your child spend every day in front of a computer, tablet, or other electronic display device to engage in learning activities?

Less than one hour daily

1-2 hours daily

2-3 hours daily

More than three hours daily

8. What problems did your child encounter in the distance learning process?

Insufficient level of digital skills

Lack of internet access or connection problems

Lack of a high-performance computer, tablet or phone

Technical difficulties in connecting on certain platforms

Emotional nature issues, closely related to the sudden suspension of preuniversity courses or to the evolution of the current epidemiological context

He did not face difficulties, the learning taking place in very good conditions

Another answer option such as: 


\section{PARENTS' OPINION REGARDING THE USE OF DISTANCE LEARNING \\ DURING COVID-19 PANDEMIC}

\section{What is the level of students' motivation for learning, in the context of the suspension of face-to-face teaching activities?}

It became lower than usual

It remained unchanged

It became higher than usual

\section{What is pupils' opinion about online learning?}

They consider online learning activities attractive or very attractive and want to organize such activities occasionally, even after starting school.

They find online learning activities attractive or very attractive, but they do not want this type of activity to take place after school starts.

They do not like to carry out online learning activities

Another answer option, namely:

11. What do you think would be the best time for schools to implement health education programs, which include information and educational counseling activities for students?

I believe that the activities should be carried out before the end of this epidemic, in the online environment

I believe that activities should take place immediately after the outbreak and should be organized in schools.

I do not consider necessary the organization of this type of educational activities

Another answer, namely:

12. In the event that there will be an extended period of suspension of schooling, what do you think would be the right option for the recovery of the subject?

Continuing the teaching activities carried out in the online environment

Extension of the school year during the summer holidays

Repetition of the school year

Gradual recovery of the subject, including in the next school year 

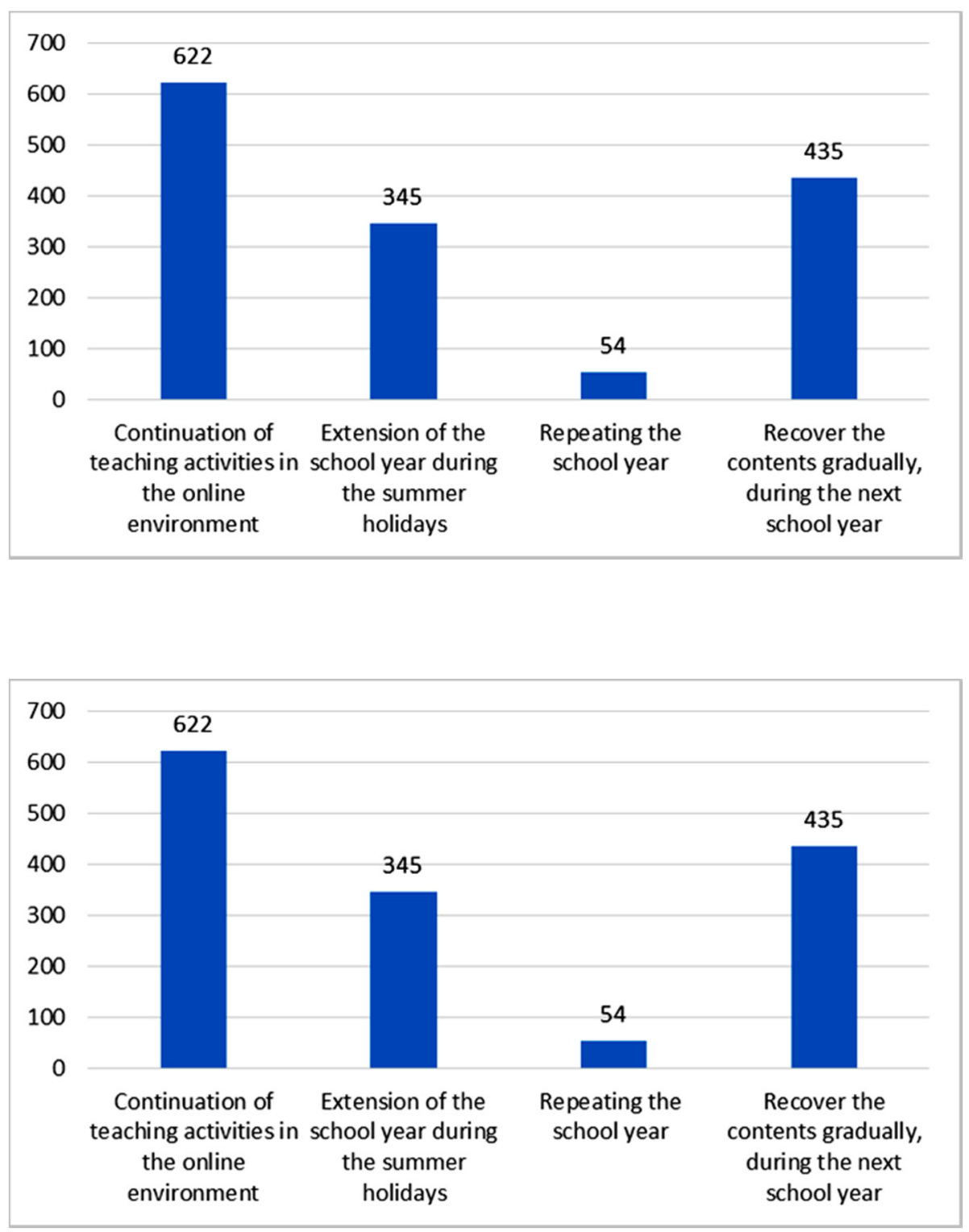